\title{
MENGELOLA PERUBAHAN DALAM ORGANISASI
}

$\begin{array}{cc} & \text { Oleh: } \\ & \text { Sutirman } \\ \text { Abstrak } & \text { FIS UNY }\end{array}$

Perubahan pada dasarnya adalah menjadikan sesuatu yang ada saat ini menjadi sesuatu yang baru yang dinginkan. Perubahan dapat disebabkan oleh faktor internal dan faktor eksternal. Faktor internal berupa kekuatan yang muncul dari dalam organisasi seperti : sumber daya manusia, perilaku, dan keputusan manajemen. Sedangkan faktor eksternal berupa kekuatan dari luar organisasi : karakterisitik demografis, perkembangan teknologi, perubahan sosial dan politik.

Mengelola perubahan dalam organisasi harus melalui tahapantahapan tertentu, yaitu : menetapkan kebutuhan untuk melakukan perubahan, mengenali faktor-faktor penghambat, melaksanakan perubahan, dan mengevaluasi perubahan. Agar perubahan organisasi dapat berjalan dengan baik maka perlu diperhatikan prinsip-prinsip manajemen perubahan yang meliputi : perubahan harus benar-benar diinginkan, adanya penaggung jawab, realistis, mengetahui kendala yang akan dihadapi, bersikap positif, optimis, serta harus bersyukur.

Perubahan dalam organisasi dapat menimbulkan reaksi atau perlawanan dari para anggota atau bawahan. Tipe-tipe perlawanan yang muncul terhadap perubahan terdiri dari : tipe perlawanan logis (keberatan rasional), tipe perlawanan psikologis (sikap emosional), dan tipe perlawanan sosiologis (kepentingan kelompok). Untuk mengatasi reaksi negatif terhadap perubahan dapat dilakukan beberapa macam pendekatan yaitu : pendidikan dan komunikasi, partisipasi dan pelibatan, fasilitas dan dukungan, negosiasi dan persetujuan, manipulasi dan kooptasi, serta penekanan. Penerapan pendekatan tersebut disesuaikan dengan situasi, kondisi, dan tujuan dari perubahan yang diinginkan.

Kata kunci : Perubahan, organisasi, Pengelolaan

\section{Pendahuluan}

Setiap organisasi yang ada di masyarakat baik organisasi bisnis, sosial, maupun politik senantias. berusaha untuk meningkatkan pro duktivitasnya. Upaya peningkataı produktivitas organisasi yang dila 
kukan biasanya akan menimbulkan dampak terhadap terjadinya perubahan dalam organisasi tersebut. Munculnya perubahan dalam organisasi seringkali menjadi ancaman bagi sebagian pihak yang ada di dalamnya. Namun demikian di era yang sangat dinamis seperti sekarang ini, kemungkinan terjadinya perubahan dalam sebuah komunitas sangat sulit dihindari.

Reorganisasi, restrukturisasi, dan rasionalisasi dalam suatu organisasi akan menjadi kecenderungan yang terus dihadapi oleh para praktisi sumber daya manusia dalam rangka memperbaiki produktivitas lembaganya. Kondisi yang demikian seringkali menimbulkan dampak yang besar terhadap tenaga kerja, seperti : hilangnya posisi jabatan tertentu, terjadinya pengangguran, berkurangnya keamanan kerja, serta berubahnya sistem kerja.

Seiring dengan terjadinya perubahan kondisi ekonomi nasional, politik, maupun perkembangan teknologi yang begitu cepat, maka setiap organisasi dituntut untuk mampu menyesuaikan diri. Demikian pula akibat adanya visi dan misi baru, strategi baru, serta perubahan kondisi sumber daya manusia dan budaya organisasi mengharuskan setiap pengelola organisasi peka untuk melakukan adaptasi. Dengan kata lain, apabila sebuah organisasi menghendaki kemajuan maka mau tidak mau harus mengikuti gejala perubahan yang terjadi baik eksternal maupun internal.

Perubahan adalah fenomena yang bersifat universal, sehingga selalu terjadi di mana saja, kapan saja, dan oleh siapa saja. Sehingga sering dikatakan bahwa tidak ada sesuatu yang tidak berubah kecuali perubahan itu sendiri.

\section{Sumber-Sumber Perubahan}

Banyak hal yang mendorong munculnya kebutuhan untuk melakukan perubahan dalam suatu organisasi. Heifetz seperti dikutip oleh Wustari Mangunjaya (2001) membedakan dua sumber perubahan yaitu sumber eksternal dan sumber internal. Menurut Heifetz, sumber eksternal meliputi :

a. Kondisi ekonomi nasional

b. Nilai-nilai politik

c. Perubahan kondisi pasar

d. Teknologi baru

e. Peraturan baru

f. Standar dan kualitas baru Sedangkan sumber perubahan internal mencakup :

a. Visi, misi dan filosofi baru

b. Strategi baru

c. Redefinisi core business

d. Restrukturisasi dan reengineering organisasi

e. Kondisi sumber daya manusia

f. Perubahan budaya organisasi

Robert Kreitner dan Angelo Kinicki dalam bukunya Organizational Behavior seperti dikutip oleh Arbono Lasmahadi (2002) menya- 
takan bahwa ada dua kekuatan yang dapat mendorong munculnya kebutuhan untuk melakukan perubahan dalam organisasi perusahaan, yaitu :

1. Kekuatan eksternal, yaitu kekuatan yang muncul dari luar perusahaan, seperti : karakteristik demografis, perkembangan teknologi, perubahan-perubahan di pasar, tekanan-tekanan sosial dan politik.

2. Kekuatan internal, yaitu kekuatan yang muncul dari dalam perusahaan itu sendiri, seperti : persoalan sumber daya manusia (kekurangan tenaga kerja, ketidakpuasan kerja, produktivitas, motivasi), perilaku, dan keputusan manajemen.

Kekuatan-kekuatan eksternal dan internal yang menjadi sumber perubahan sering saling berhubungan. Hubungan ini terutama sebagai hasil dari perubahan-perubahan dalam nilai dan sikap yang mempengaruhi orang dalam sistem. Orangorang dengan berbagai karakter yang berbeda memasuki organisasi dan menyebabkan perubahan dari dalam (T Hani Handoko : 1992).

\section{Tahapan Perubahan}

Raymond J. Stone seorang konsultan sumber daya manusia dalam bukunya Human Resources Management membagi langkahlangkah yang harus dilakukan dalam mengelola perubahan menjadi empat tahap, yaitu :
1. Menetapkan kebutuhan untuk melakukan perubahan.

Langkah ini dianggap penting untuk memastikan bahwa perubahan yang akan dilakukan benar-benai sesuai dengan kebutuhan riil yang hendak dicapai. Kebutuhan terhadap adanya perubahan dapat muncul apabila terdapat kesenjangan antara sasaran yang ingin dicapai ololi organisasi dengan kondisi nyata di lapangan.

2. Mengenali hal-hal potensial yang dapat menghambat proses peri. bahan.

Pimpinan organisasi sebagal pelaksana perubahan harus mampu mengenali hal-hal yang secara po tensial dapat menghambat prosos perubahan. Misalnya :

a. Karyawan tidak bersedia untuk di PHK karena sulit mencali pekerjaan baru.

b. Karyawan tidak sepakat dengan paket perubahan yang ditawar kan oleh perusahaan.

c. Adanya kemungkinan keterliba tan pihak luar.

d. Adanya friksi antar sesama kar yawan.

3. Melaksanakan perubahan.

Menurut Stone (1998), peru bahan dapat diperkenalkan oleh $\mathrm{ma}$ najer perusahaan atau memanfaal kan jasa konsultan. Keduanya mem punyai kelebihan dan kekurangan Apabila manajer internal menjadi agen perubahan, maka ia sudah sa ngat memahami operasi perusahaan 
dan orang-orang yang ada di dalamnya, tetapi biasanya manajer internal mempunyai wawasan dan cara pandang yang terbatas mengenai pengelolaan perubahan. Sedangkan kelebihan dari konsultan adalah lebih bersifat netral dan mempunyai wawasan yang luas terhadap pengelolaan perubahan. Kekurangannya adalah ia kurang memahami operasi perusahaan dan orang-orang yang bekerja di dalamnya. Untuk mengatasi kekurangan dari kedua pendekatan tersebut, perusahaan sebaiknya melakukan kombinasi dalam memperkenalkan perubahan kepada orang-orang dalam organisasi perusahaan tersebut.

4. Mengevaluasi perubahan.

Agar efektifitas perubahan dapat terukur dengan baik, perusahaan perlu membandingkan situasi sebeum dan sesudah dilakukannya perubahan. Ada beberapa indikator yang dapat digunakan untuk mengukur pengaruh dari perubahan, seperti : produktivitas karyawan, kepuasan kerja, pendapat karyawan, hasil penjualan, serta pengurangan biaya produksi.

Veithzal Rivai dalam bukunya yang berjudul Kepemimpinan dan Perilaku Organisasi (2004) menjelaskan adanya tiga tahap perubahan, meliputi :

a. Tahap Pencairan (unfreezing)

Yaitu tahapan menghilangkan ide-ide dan praktik yang sudah berlaku dan memperkenalkan ide-ide dan praktik baru.

\section{b. Perubahan (change).}

Adalah tahapan mempelajari ide-ide dan praktik baru. Tahap ini meliputi : membantu pemikiran karyawan, alasan-alasan, dan penampilan dengan cara-cara baru. Tahap ini dianggap sebagai saat-saat yang membingungkan, tanpa arah yang jelas, beban yang berlebihan, dan kekecewaan. Di sisi lain, harapanharapan, penemuan-penemuan baru, dan kenikmatan-kenikmatan baru juga muncul pada tahapan ini.

c. Pembekuan ulang (refreezing).

Yaitu tahapan di mana segala sesuatu yang telah dipelajari diintegrasikan ke dalam praktik nyata dalam organisasi. Dalam tahapan ini, praktik-praktik baru harus disatukan ke dalam tingkah iaku karyawan sehari-hari agar ide-ide baru dapat diterima secara intelektual.

\section{Sikap dalam Menghadapi Peru- bahan}

Sikap dalam menghadapi perubahan dapat terdiri dari tingkah laku karyawan yang didesain untuk tidak mempercayai, menunda, dan mencegah implementasi dari perubahan kerja. Biasanya karyawan melakukan perlawanan terhadap adanya perubahan kerja dikarenakan faktor keamanan, interaksi soial, status, dan kepercayaan dirinya yang terancam. 
Menurut Veithzal Rivai terdapat tiga tipe sikap perlawanan terhadap perubahan kerja suatu orga- nisasi perusahaan. Ketiga tipe terse but dapat diilustrasikan dalam table berikut :

Tabel. Tipe-tipe Perlawanan Terhadap Perubahan di antara Karyawan

\begin{tabular}{|c|c|}
\hline Tipe Perlawanan & Indikator \\
\hline 1. Logis (Keberatan Rasional & $\begin{array}{l}\text { a. Waktu yang diperlukan untuk } \\
\text { perubahan } \\
\text { b. Usaha ekstra untuk kembali belajar } \\
\text { c. Kemungkinan kondisi yang } \\
\text { diinginkan lebih rendah } \\
\text { d. Biaya ekonomiatas perubahan } \\
\text { e. Masalah-masalah teknis atas } \\
\text { perubahan }\end{array}$ \\
\hline 2. Psikologis (Sikap Emosional) & $\begin{array}{l}\text { a. Ketakutan yang tidak jelas } \\
\text { b. Toleransi yang rendah. terhadap } \\
\text { perubahan } \\
\text { c. Ketidaksenangan manajemen atau } \\
\text { agen peprubahan lain } \\
\text { d. Kurangnya kepercayaan pada pihak } \\
\text { lain } \\
\text { e. Kebutuhan keamanan dan } \\
\text { keinginan untuk mepertahankan } \\
\text { status quo }\end{array}$ \\
\hline 3. Sosiologis (Kepentingan Kelompok) & $\begin{array}{l}\text { a. Koalisi politik } \\
\text { b. Menentang nilai-nilai kelompok } \\
\text { c. Pandangan yang sempit } \\
\text { d. Kepentingan } \\
\text { e. Keinginan mempertahankan perte-- } \\
\text { manan yang ada }\end{array}$ \\
\hline
\end{tabular}

Sumber : Veithzal Rivai, 2004:442

Sedangkan menurut Wustari Mangunjaya dalam Bertina S dkk. (2001) mengutip pendapatnya Fales \& White, sikap dalam menghadapi perubahan dikelompokkan menjadi empat macam, yaitu :

a. Logika Rasional
Sikap ini ditunjukkan dengan perilaku yang tidak emosional, fokus terhadap logika dan rasional, tertarik pada fakta dan implementasi, fokus pada analisa peristiwa dan implikasi, dan cenderung mengevaluasi dan mencari jawaban. 


\section{b. Positif dan Kreatif}

Orang yang memiliki sikap ini cenderung menikmati perubahan, berani mengambil resiko, ingin berperan dalam perubahan yang akan datang, tidak terlibat secara emosional, fokus pada dinamika perubahan, banyak ide dan pertanyaan, serta melakukan penjajagan mengenai konsekuensi dari perubahan.

\section{c. Kontrol Negatif}

Sikap ini lebih emosional, berpikir dan bersikap negatif, orientasi pada diri sendiri, mencari aman, menolak perubahan, melawan organisasi dan lingkungan, dan melawan dengan tidak logis.

\section{d. Fokus Terhadap Manusia}

Sikap ini dicirikan dengan perilaku individu yang suka menjajagi pengalaman perubahan, lebih emosional daripada intelektual, lebih fokus pada orang lain yang terpengaruh perubahan, bertukar pengalaman dengan orang lain, serta mendukung orang lain yang terkena dampak perubahan.

Dari keempat sikap tersebut, sikap Logika Rasional dan Positif Kreatif oleh Fales \& White dianggap sebagai sikap intelektual. Sebaliknya, sikap Fokus Terhadap Manusia dan Kontrol Negatif dianggap sebagai sikap yang emosional.

\section{Kegagalan Mengelola Perubahan}

Banyak perusahaan yang mengalami kegagalan pada saat melakukan perubahan, dan berakibat tim- bulnya kerugian secara finansial. Kegagalan tersebut umumnya disebabkan oleh kesalahan-kesalahan yang dibuat pada saat mengelola perubahan. Kesalahan-kesalahan yang lazim dilakukan antara lain :

1. Mengabaikan aspek manusia dalam mengelola perubahan

Timothy J. Galpin dalam bukunya The Human Side of Change sebagaimana dikutip oleh Arbono L (2002) menyatakan bahwa selama proses penggabungan perusahaan, penurunan besarnya ukuran perusahaan, maupun restrukturisasi yang dilakukan, kebanyakan dari mereka lebih memusatkan perhatiannya kepada aspek-aspek teknis, finansial, dan operasional daripada aspek manusia. Kurangnya perhatian terhadap aspek manusia ini berakibat gagalnya upaya perubahan yang dilakukan. Hal tersebut dapat terjadi dalam bentuk persoalan tenaga kerja, keluarnya tokoh-tokoh kunci dan orangorang berbakat dari perusahaan, dan tidak adanya manfaat atau sangat sedikit manfaat yang diperoleh dari perubahan yang dilakukan.

2. Perubahan tidak dilaksanakan dengan baik

Banyak perusahaan yang memberlakukan perubahan seperti sebuah peristiwa kebetulan atau hal rutin yang akan dapat diselesaikan dengan baik secara otomatis, tanpa perencanaan yang matang. Padahal menurut seorang Pakar Perilaku di Dalam Perusahaan Stephen Robin, 
perubahan seharusnya merupakan sebuah aktivitas yang terencana, disengaja, dan berorientasi pada tujuan. Tujuan dari suatu perubahan menurutnya adalah : (1) meningkatkan kemampuan perusahaan dalam beradaptasi terhadap peruabahan yang terjadi di lingkungannya, (2) merubah tingkah laku dari para karyawan. Apabila perubahan tidak direncanakan dengan baik, maka perubahan akan bergulir tanpa kendali, tidak sesuai dengan rencana yang diharapkan, karena mendapat perlawanan dari para karyawan.

3. Praktisi perubahan gagal membangun koalisi yang cukup kuat.

Menurut Kotter, salah satu penyebab kegagalan yang dialami oleh perusahaan dalam melakukan perubahan adalah tidak terbentuknya koalisi yang cukup kuat diantara orangorang yang mempunyai wewenang dan kemampuan untuk mendukung perubahan. Upaya perubahan yang dilakukan tanpa dukungan koalisi yang cukup mungkin dapat mengalami kemajuan untuk sementara waktu. Namun cepat atau lambat, akan muncul perlawanan yang akhirnya dapat merusak inisiatif perubahan yang telah berjalan.

Dampak utama yang perlu mendapat perhatian akibat kesalahan-kesalahan yang dilakukan adalah munculnya resistensi dari para manajer dan karyawan yang terkait dengan perubahan. Kreitner dan Kinicki mendefinisikan resistensi terha- dap perubahan sebagai suatu reaks emosional yang muncul sebagai res. pon terhadap munculnya ancaman, baik nyata atau tidak nyata bila tor jadi perubahan pada pekerjaan rutin

Resistensi terhadap peruba han ini dapat muncul dalam berbagal macam bentuk reaksi. Judson seperll dikutip oleh Kreitner dan Kinikcl menggolongkan bentuk-bentuk resis. tensi terhadap perubahan menjadi empat kelompok, yaitu : resistensi aktif (sabotase, memperlambat ker. ja), resistensi pasif (bekerja sesedikil mungkin, tidak tertarik mempelajari tugas baru), reaksi yang tidak dapal dibedakan (bekerja hanya berdasar kan perintah, kehilangan minat terha dap pekerjaan), dan penerimaan (mau bekerja sama, antusias).

Selain kesalahan-kesalahan yang sering dilakukan oleh praktisi perubahan, ternyata masih ada faktor lain yang menjadi penyebab terjadi nya resistensi terhadap perubahan Menurut Robin dan Kreitner \& Kinikci, faktor-faktor tersebut adalah :

a. Kebiasaan

Pada dasarnya manusia ada lah mahluk yang hidup dari kebiasa an yang dibangunnya. Kebiasaan in akan lebih mempermudah manusia dalam melakukan kehidupannya yang sangat kompleks. Saat diha dapkan pada perubahan, maka ma nusia akan cenderung enggan me rubah kebiasaan yang telah dijalani nya selama ini. Contoh sederhana seseorang akan cenderung memilih 
rute perjalanan menuju kantor yang biasa dilaluinya setiap hari meskipun ada rute lain yang jaraknya lebih pendek tetapi belum ia kenal dengan baik.

b. Ketakutan terhadap munculnya dampak yang tidak diinginkan

Perubahan tidak jarang menimbulkan ketidakpastian, karena perubahan membuat seseorang bergerak dari satu situasi yang ia ketahui menuju situasi lain yang belum ia ketahui. Akibatnya individu yang menghadapi perubahan tersebut akan merasa takut akan dampak yang mungkin merugikan dirinya.

\section{c. Faktor-faktor Ekonomi}

Berkurangnya penghasilan, kenaikan gaji yang tidak sesuai harapan, meningkatnya ongkos angkutan, merupakan sebagian faktor ekonomi yang dapat menjadi penyebab munculnya resistensi terhadap perubahan. Apabila perubahan mengakibatkan dampak ekonomi yang besar terhadap seseorang, maka dapat diprediksi bahwa resistensi dari orang yang bersangkutan akan semakin kuat.

d. Tidak adanya kepercayaan dalam situasi kerja

Seorang pimpinan yang membangun hubungan kerja dengan bawahannya atas dasar ketidakpercayaan, akan lebih mungkin menghadapi resistensi jika ia menggulirkan rencana perubahan. Sementara seorang pimpinan yang mempercayai bawahannya akan memperlakukan perubahan sebagai hal yang sifatnya terbuka, jujur, dan partisipatif. Demikian pula seorang bawahan yang dipercaya oleh atasannya akan melakukan upaya yang lebih baik dalam menghadapi perubahan dan memandang perubahan sebagai sebuah peluang.

e. Takut mengalami kegagalan

Proses perubahan pada pekerjaan yang bersifat menekan karyawan akan memunculkan keraguan pada karyawan tersebut akan kemampuannya untuk melakukan pekerjaan dengan baik. Keraguan ini dalam jangka panjang akan mengikis kepercayaan dirinya dan melumpuhkan potensi yang dimiliki.

f. Hilangnya status atau keamanan kerja

Pemanfaatan teknologi atau sistem administrasi baru dalam dunia kerja, pada satu sisi dapat mompercepat proses penyelesaian pekerjaan. Namun pada sisi lain akan mengakibatkan berkurangnya jumlah pekerjaan. Dampak inilah yang sering dikhawatirkan oleh para pegawai bila terjadi perubahan. Bagi sebagian besar karyawan hilangnya pekerjaan dapat diartikan sebagai hilangnya status dan hancurnya perekonomian keluarga. Untuk alasan inilah para pegawai atau karyawan bersikap resisten terhadap perubahan.

g. Tidak ada manfaat yang diperoleh dari perubahan

Seseorang akan melakukan resisten tehadap perubahan jika yang 
bersangkutan memperkirakan dirinya tidak akan memperoleh manfaat atas perubahan tersebut (Arbono $\mathrm{L}$ : 2002).

Untuk meminimalisir kemungkinan terjadinya resistensi terhadap perubahan yang akan dilaksanakan dalam perusahaan, pihak manajemen harus memperhatikan dan mempertimbangkan prinsip-prinsip manajemen perubahan sebelum perubahan itu diterapkan. Prinsip-prinsip tersebut adalah:

1. Perubahan benar-benar diinginkan

Sebelum suatu organisasi melaksanakan perubahan, maka terlebih dahulu harus dikaji apakah perubahan tersebut benar-benar diinginkan. Kalau ternyata memang mengharuskan adanya perubahan, maka perlu dikaji pula perubahan dalam ha! apa saja yang harus dilakukan.

\section{Adanya penanggung jawab}

Setiap kebijakan sebuah organisasi mutlak diperlukan penanggung jawab, termasuk penanggung jawab untuk perubahan. Seorang penanggung jawab haruslah sesorang yang memahami situasi organisasi dan memahami konsep perubahan yang akan digulirkan.

3. Harus realistis

Perubahan akan dapat dilaksanakan dengan baik apabila perubahan yang dilakukan adalah sesuatu yang realistis, dengan memperhatikan segala potensi yang ada dalam perusahaan.
4. Harus mengetahui kendala yang dihadapi

Dengan mengetahui kendala yang mungkin dihadapi dalam melontarkan ide perubahan, maka akan lebih mudah mencari alternatif solusi untuk mengatasi kendala-kendala tersebut.

4. Harus memiliki sikap positif

Sikap positif harus dibangun oleh kedua belah pihak, baik dari atasan terhadap bawahan maupun dari bawahan terhadap atasan. Untuk menumbuhkan sikap positif terhadap perubahan, maka terlebih dahulu ha rus dilakukan sosialiasi mengenai tujuan, alasan, dan dampak dari perubahan kepada seluruh komponen organisasi.

5. Harus optimis

Sikap optimis sangat diperlukan dalam memulai sesuatu hal baru, agar mampu bekerja dengan konsisten sehingga dapat meraih hasil yang maksimal.

6. Harus bersyukur

Rasa syukur merupakan wujud kebesaran jiwa dalam menerima sesuatu, sehingga perubahan yang terjadi akan mampu menghasilkan halhal baru yang lebih positif (Bertina $S$, dkk. : 2001)

\section{Beberapa Saran}

Ada beberapa alternatif lang kah yang dapat ditempuh oleh para praktisi sumber daya manusia dalam mengelola perubahan, yaitu : 
1. Rencanakan perubahan dengan baik

Sebelum perubahan digulirkan, maka pihak-pihak yang terkait dengan perubahan (misalnya : manajemen puncak, para menejer, dan agen perubahan) perlu merencanakannya denga matang. Langkahlangkah perencanaan tersebut adalah sebagai berikut:

a. Melakukan analisa yang mendalam tentang ada tidaknya kebutuhan untuk melakukan perubahan dalam organisasi.

b. Merumuskan tujuan yang ingin dicapai dari perubahan dan dampak yang mungkin ditimbulkan.

c. Mengenali faktor-faktor yang dapat menghambat terjadinya perubahan dan cara mengatasinya.

d. Menyusun strategi yang tepat untuk menggulirkan perubahan.

e. Mempersiapkan parameter-parameter dan pendekatan yang akan digunakan untuk mengevaluasi perubahan.

2. Menunjuk praktisi perubahan yang mempunyai kemampuan dalam mengelola perubahan.

Agar perubahan dapat berjalan sesuai dengan yang diharapkan, maka personel yang ditunjuk sebagai ujung tombak perubahan harus mempunyai pengalaman, keirampilan, dan pengetahuan yang baik dalam aspekaspek yang berkaitan dengan penge- lolaan perubahan. Orang tersebut sebaiknya memiliki kompetensi dalam bidang perilaku organisasi, pengembangan organisasi, teori-teori belajar, teori motivasi, dan kepemimpinan.

3. Membekali manajemen puncak dengan pengetahuan dan ketrampilan mengenai pengelolaan perubahan.

Hal ini dapat dilakukan dengan cara mengundang pakar dibidang perubahan untuk mendiskusikan mengenai pengelolaan perubahan yang tepat sesuai dengan situasi, kondisi, dan karakteristik organisasi. Selain itu dapat pula dilakukan dengan cara studi banding ke organisasi lain yang sejenis yang telah sukses melakukan perubahan.

4. Membangun koalisi yang solid di antara pihak-pihak yang terkait dengan perubahan.

Para pimpinan, baik di tingkat puncak, menengah, maupun bawah beserta para pelaksanan perubahan lainnya harus bekerja sama dalam sebuah tim yang solid dalam menggerakkan perubahan tersebut. Dengan demikian akan memperkuat dukungan terhadap perubahan dan mencegah terjadinya resistensi terhadap gagasan perubahan yang dijalankan.

5. Mengatasi resistensi terhadap perubahan dengan pendekatan yang sesuai

Untuk memastikan bahwa proses perubahan dapat berlangsung 
sesuai rencana, maka reaksi-reaksi yang muncul harus dapat diatasi. Menurut Kreitr.^r \& Kinicki (2001) untuk mengatasi terjadinya resistensi dapat dilakukan dengan pendekatan sebagai berikut:

\section{a. Pendidikan dan komunikasi}

Pendekatan ini dilakukan apabila informasi dan analisis yang akurat tentang perubahan kurang atau sangat terbatas.

b. Partisipasi dan pelibatan

Pendekatan ini dilakukan apabila para inisiator perubahan tidak mempunyai informasi yang dibutuhkan untuk merancang perubahan, sementara ada pihak lain yang mempunyai power lebih besar.

c. Fasilitas dan dukungan

Pemberian fasilitas dan dukungan dilakukan apabila resistensi dari karyawan muncul karena masalah penyesuaian diri.

d. Negosiasi dan persetujuan

Upaya ini dilakukan apabila seorang karyawan atau sekelompok karyawan secara pasti akan terkena dampak dari perubahan, sementara mereka mempunyai kekuatan yang cukup untuk melakukan perlawanan.

e. Manipulasi dan kooptasi

Hanya dilakukan apabila pendekatan lain tidak dapat digunakan atau terlalu mahal, akan tetapi beresiko dikemudian hari jika diketahui terjadi manipulasi.

\section{f. Penekanan}

Pendekatan ini dilakukan jika dibutuhkab waktu yang cepat untuk melakukan perubahan, dan para inisiator memiliki kekuasaan yang yang cukup besar. Akan tetapi pendekatan ini sangat beresiko, apabila muncul reaksi yang negatif dari pawa bawahan (Arbono L : 2002).

\section{Penutup}

Perubahan dalam berbagai bentuknya pada dasarnya ditujukan untuk memberikan dampak yang positif bagi pertumbuhan dan per kembangan perusahaan. Para pakar meramalkan bahwa kebutuhan untuk melakukan perubahan baik yang didorong oleh faktor eksternal mau pun internal akan terus muncul dalam setiap organisasi. Hal ini akan mem. berikan dampak terhadap kelang sungan hubungan kerja di dalam tu buh organisasi.

Bagi para praktisi sumber daya manusia atau praktisi perubahan. kecenderungan ini akan menjadi tantangan yang menarik bila mereka dapat memberikan respon terhadap langkah perubahan yang terjadi dan mengelolanya dengan baik. Sebaliknya akan menjadi ancaman terhadap karir bila mereka tidak mampu memberikan respon yang baik terhadap tuntutan perubahan.

Oleh karena itu agar tidak menjadi pihak yang gagal maka seorang praktisi sumber daya manusia atau praktisi perubahan dituntut untuk memiliki pemahaman dan penguasaan terhadap aspek-aspek yang berkaitan dengan pengelolaan 
perubahan di dalam organisasi, khususnya yang berkaitan dengan aspek sumber daya manusia. Berbekal pengetahuan dan ketrampilan yang dimiliki dalam mengelola perubahan, maka seorang praktisi sumber daya manusia atau praktisi perubahan akan dapat melaksnakan perubahan secara efektif, sesuai dengan tujuan yang ingin dicapai.

\section{Daftar Pustaka}

Veitzal Rivai. 2004. Kepemimpinan dan Perilaku Organisasi. Jakarta : Raja Grafindo Persa-da. Bertina Sjabandhyni, dkk. 2001. Pengembangan Kualitas SDM dari Perspektif PIO. Ja-karta : Fakultas Psikologi UI.
Arbono Lasmahadi. 2002. Perubahan dalam Perusahaan, Tantangan atau Ancaman?. Jakarta : e-psikologi.com

\section{Biodata Penulis}

Sutirman, lahir di Cilacap tanggal 3 Januari 1972 adalah Asisten Dosen (CPNS) pada program studi Pendidikan Administrasi Perkantoran Fakultas IImu Sosial Universitas Negeri Yogyakarta. 